UDC 539

DOI: http://dx.doi.org/10.20535/2521-1943.2017.81.117489

\title{
Effectiveness of ultrasonic peening in fatigue improvement of welded elements and structures
}

\author{
Jacob Kleiman $^{1} \bullet$ Yuri Kudryavtsev ${ }^{1} \bullet$ Oleksandr Luhovskyi $^{2}$ \\ 1 - Structural Integrity Technologies Inc., Markham, Ontario, Canada; \\ 2 - Igor Sikorsky Kyiv Polytechnic Institute, Kyiv, Ukraine
}

Received: 19 October 2017 / Accepted: 27 November 2017

\begin{abstract}
The ultrasonic impact treatment (UIT) is relatively new and promising process for fatigue life improvement of welded elements and structures. In most industrial applications this process is known as ultrasonic peening (UP). The beneficial effect of UP is achieved mainly by relieving of tensile residual stresses and introducing of compressive residual stresses into surface layers of a material. The secondary factors in fatigue improvement by UP are decreasing of stress concentration in weld toe zones and enhancement of mechanical properties of the surface layers of the material. Fatigue testing of welded specimens showed that UP is the most efficient improvement treatment as compared with traditional techniques such as grinding, TIG-dressing, heat treatment, hammer peening and application of LTT electrodes. The developed computerized complex for UP was successfully applied for increasing the fatigue life and corrosion resistance of welded elements, elimination of distortions caused by welding and other technological processes, residual stress relieving, increasing of the hardness of the surface of materials. The UP could be effectively applied for fatigue life improvement during manufacturing, rehabilitation and repair of welded elements and structures. The areas/industries where the UP process was applied successfully include: Shipbuilding, Railway and Highway Bridges, Construction Equipment, Mining, Automotive, Aerospace. The results of fatigue testing of welded elements in as-welded condition and after application of UP are considered in this paper. It is shown that UP is the most effective and economic technique for increasing of fatigue strength of welded elements in materials of different strength. These results also show a strong tendency of increasing of fatigue strength of welded elements after application of UP with the increase in mechanical properties of the material used.
\end{abstract}

Keywords: residual stresses; ultrasonic peening method; underwater ultrasonic peening; UltraPeen ${ }^{\circledR}$; fatigue life

\section{Introduction}

The ultrasonic impact treatment (UIT) is one of the most efficient techniques for fatigue life improvement of welded elements and structures [1-7]. In most industrial applications this process is also known as ultrasonic peening (UP) [8-12]. The beneficial effect of UIT/UP is achieved mainly by relieving of harmful tensile residual stresses and introducing of compressive residual stresses into surface layers of materials, decreasing of stress concentration in weld toe zones and enhancement of mechanical properties of surface layers of the material. The fatigue testing of welded specimens showed that the UP is the most efficient improvement treatment when compared with such traditional techniques as grinding, TIG-dressing, heat treatment, hammer peening, shot peening and application of LTT electrodes $[1,13,14]$.

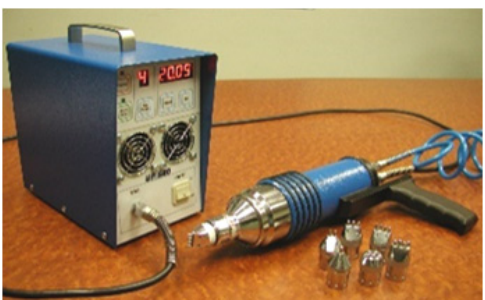

$a$

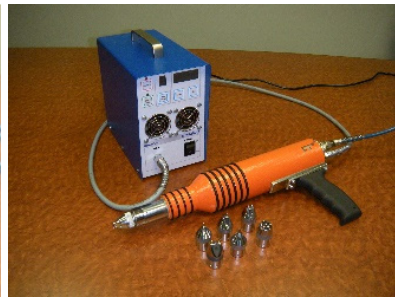

$b$

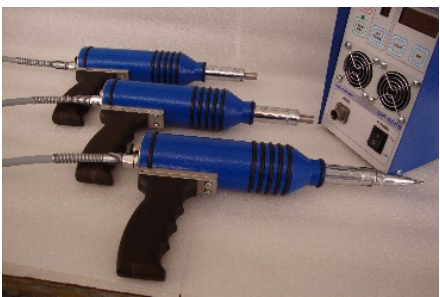

$c$

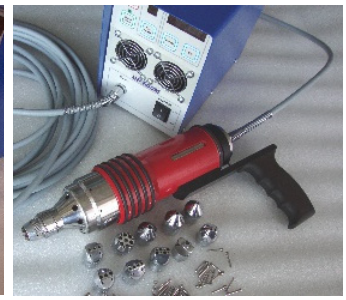

$d$

Fig. 1. Different modifications of the basic ultrasonic peening system for fatigue life improvement of welded elements and structures 
A number of ultrasonic peening systems were developed for different applications (Fig.1). All of them include an ultrasonic generator $(20-27 \mathrm{kHz})$ and a treatment tool with an ultrasonic piezoceramic transducer that converts the ultrasonic energy into mechanical motion of special freely moving strikers. Special software for optimum application of UP, i.e. maximum possible increase in fatigue life of parts and welded elements with minimum cost, labor and power consumption was also developed. The developed UP systems shown in Figure 1 could be used for treatment of weld toes and larger surface areas. UP Systems were designed to allow the operator to use them conveniently in horizontal and vertical applications (Fig. 1c). Recently, a new ultrasonic system (Fig. 1d) was designed to perform underwater UP at the depth of up to 30 meters [26]. The design of the UP systems is based on "Power on Demand" concept. Using this concept, the power and other operating parameters of the UP equipment are adjusted to produce the necessary changes in residual stresses, stress concentration and mechanical properties of the surface layers of materials to attain the maximum possible increase in fatigue life of welded elements and structures. From other side, this approach prevents the possibility to overwork the treated surface and decrease the efficiency of UP.

The effects of different improvement treatments, including the UP treatment, on the fatigue life of welded elements depend on the mechanical properties of used material, the type of welded joints, the parameters of cyclic loading and other factors. For effective application of UP, depending on the above-mentioned factors, a software package for Optimum Application of UP was developed that is based on original predictive model. In the optimum application, a maximum possible increase in fatigue life of welded elements with minimum time/labor/cost is thought [15].

The developed technology and computerized complex for UP were successfully applied for increasing of the fatigue life of welded elements, elimination of distortions caused by welding and other technological processes, relieving of residual stress, increasing of the hardness of the surface of materials and surface nanocrystallization. The areas/industries where the UP was applied successfully include: Railway and Highway Bridges, Construction equipment, Shipbuilding, Mining, Automotive and Aerospace, to name a few.

\section{Application of up for fatigue improvement}

The ultrasonic treatment can be applied effectively for fatigue life improvement during manufacturing, rehabilitation and repair of welded elements and structures. The areas/industries where the UP was applied successfully include: Railway and Highway Bridges, Construction Equipment, Shipbuilding, Mining, Automotive and Aerospace. An example of application of UP for repair and rehabilitation of welded elements subjected to fatigue loading in mining industry is shown in Figure 2a. Around 300 meters of welds, critical from fatigue point of view, were UP treated to provide improved fatigue performance of two large grinding mills located near Labrador City, NL, Canada (Fig. 2a)

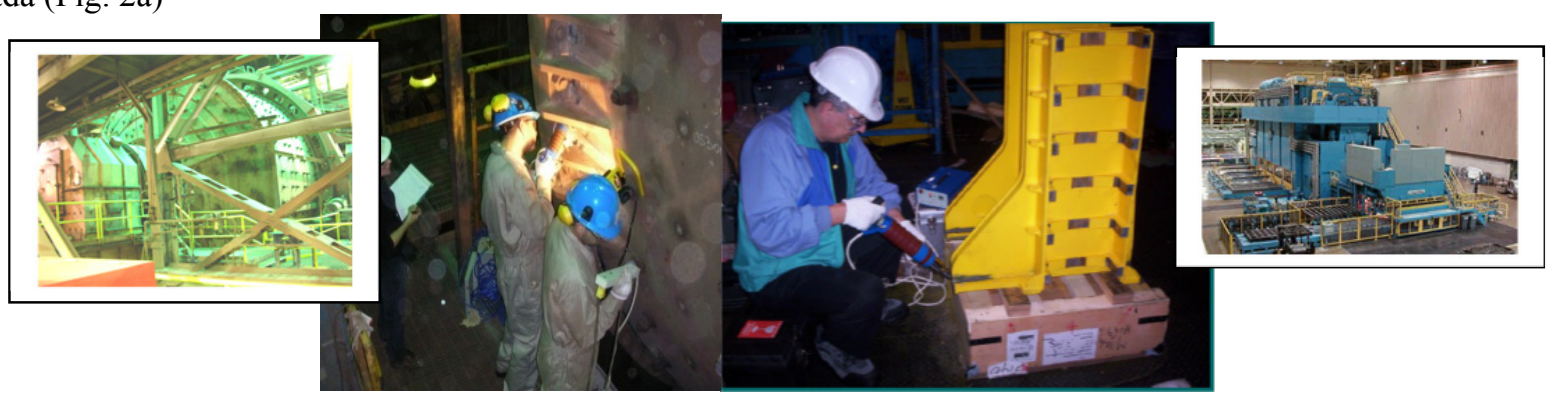

$a$

$b$

Fig. 2. Application of UP for rehabilitation of welded elements of a) a large grinding mill (left insert) and b) an automotive stamping press (right insert)

In another case, the ultrasonic peening (UP) was used successfully in an automotive stamping press with a capacity of 5400 tons and with up to 15 loading cycles per minute and about 7 millions cycles of loading per year that was stopped for regular maintenance (Fig. 2b). A few more detailed results of application of ultrasonic treatment for fatigue life improvement during manufacturing, rehabilitation and repair of welded elements and structures are discussed below.

\section{Manufacturing and Rehabilitation}

In a study aimed at evaluation of the effectiveness of UP application in welding application, three series of largescale welded samples, designed as shown in Figure 3a, were subjected to fatigue testing in as-welded condition, with UP applied before fatigue testing and with UP applied after fatigue loading with the number of cycles corresponding to $50 \%$ of the expected fatigue life of samples in as-welded condition [9].

The sample material properties were as follows: yield strength - $360 \mathrm{MPa}$, ultimate strength $-420 \mathrm{MPa}$. The samples were tested at a stress ratio $\mathrm{R}=0$. Test frequency $-5 \mathrm{~Hz}$. The UP treatment parameters were as follows: speed of treatment -0.4 meter/minute, level of the oscillation amplitude - 4 , a working head with one row of four 3 mm diameter pins was used in all tests. 

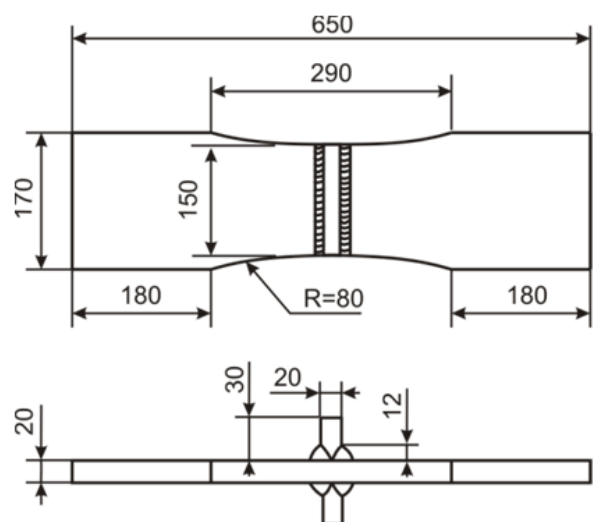

$a$

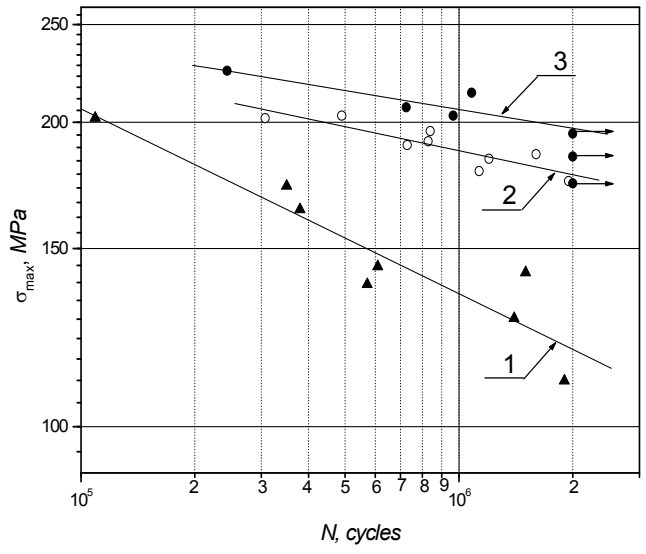

$b$

Fig. 3. Results of fatigue testing of the large-scale welded samples. a) The general view of welded sample for fatigue testing; b) Fatigue curves of welded elements (transverse non-load-carrying attachment): 1 - in as welded condition, 2 - UP was applied before fatigue testing, 3 - UP was applied after fatigue loading with the number of cycles corresponding to $50 \%$ of expected fatigue life of samples in as-welded condition

As can be seen from Fig. $3 b$ that presents the results of the fatigue testing of all three series of samples, the UP caused a significant increase in fatigue strength of the considered welded element for both series of UP treated samples (lines 2 and 3 in Fig. 3b). The increase in limit stress range at $\mathrm{N}=2 \cdot 10^{6}$ cycles of welded samples is $49 \%$ (from $119 \mathrm{MPa}$ to $177 \mathrm{MPa}$ ) for UP treated samples before fatigue loading and is $66 \%$ (from $119 \mathrm{MPa}$ to $197 \mathrm{MPa}$ ) for UP treated samples after fatigue loading, with the number of cycles corresponding to $50 \%$ of the expected fatigue life of the samples in as-welded condition. A slightly higher increase of fatigue life of UP treated welded elements for fatigue curve 3 could be explained by a more beneficial redistribution of residual stresses by UP after cyclic loading than in aswelded condition and/or by "healing" of fatigue damaged material by recrystallization [27] during UP in comparison with the fatigue curve 2 .

\section{Weld Repair}

In a different study [7, 10], UP was applied to a number of large-scale welded specimens containing non-load carrying longitudinal attachments designed for fatigue testing (Fig. 4a) to study the prevention of possible initiation of fatigue cracks in existing welded elements and structures that are in service by applying UP during the weld repair of fatigue cracks. Figure $4 \mathrm{a}$ shows the drawing of a large-scale welded specimen containing non-load carrying longitudinal attachments designed for fatigue testing [7]. Material properties: yield strength - $360 \mathrm{MPa}$, ultimate strength - $420 \mathrm{MPa}$. Such specimens were tested in as-welded condition and after weld repair with and without application of UP. The testing conditions were zero-to-tension stress cycles $(\mathrm{R}=0)$ with different level of maximum stresses. Test frequency - $5 \mathrm{~Hz}$.

The fatigue testing was stopped and the number of cycles was recorded when the length of fatigue crack on surface reached $20 \mathrm{~mm}$. Then, the fatigue crack was repaired by gouging and welding and the fatigue test was continued. After repair, a number of samples were subjected to UP. The weld toe of the "new" weld was UP treated. The results of fatigue testing of welded specimens in as-welded condition and after weld repair of fatigue cracks are presented in Figure 4b.

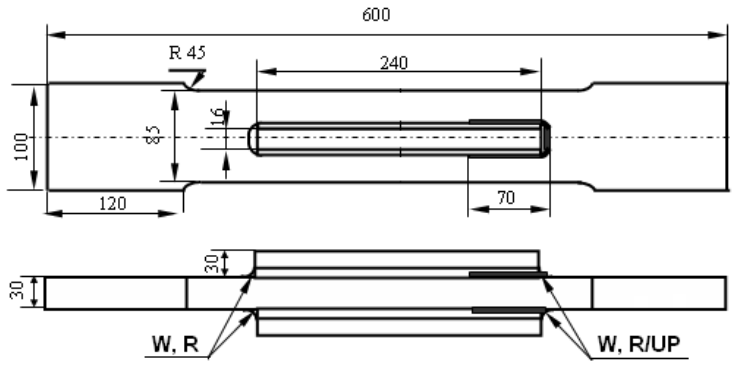

$a$

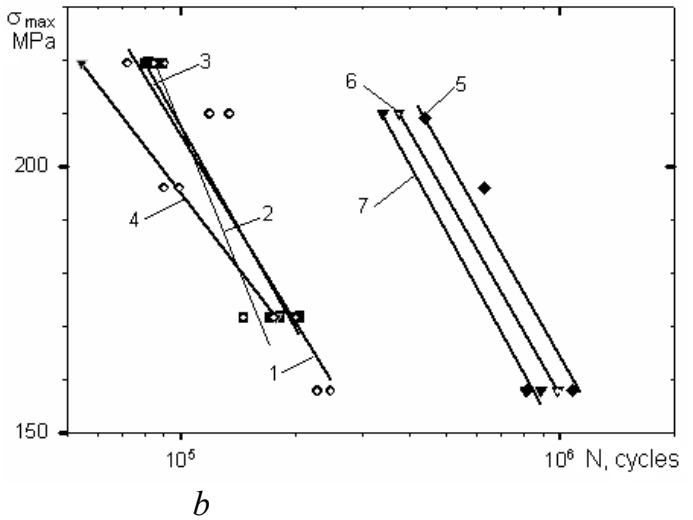

Fig. 4. Fatigue testing of large welded elements. a) Schematic drawing of the welded specimen for fatigue testing at different conditions of treatment: W - as-welded condition; $R$ - repair by gouging and welding; R/UP - repair by gouging, welding and UP; b) Results of fatigue testing of welded elements: 1 - as-welded condition, 2,3 and 4 - after first, second and third weld repair, 5, 6 and 7 - after first, second and third weld repair with application of $U P$ 
As can be seen from Fig. 4b, the fatigue testing of large scale specimens had shown that the repair of fatigue cracks by welding is restoring the fatigue strength of welded elements to the initial as-welded condition. Second and third repair of fatigue cracks also practically restored the fatigue life of repaired welded elements to initial as-welded condition (lines 2 and 3 in Fig. 4b).

The application of UP after weld repair increased the fatigue life of welded elements 3-4 times (line 5 in Fig. 4b). Practically the same significant fatigue improvement of repaired welded elements by UP is observed also after second and third repair of fatigue cracks in welded elements (lines 6 and 7 in Fig. 4b).

\section{Comparison between weld improvement treatments}

Results of two studies that are presented below show that benefits from UIT/UP are higher then from other techniques and especially strong when the treatment is applied to welded high strength steels. In one of the studies, four series of large-scale welded samples were subjected to fatigue testing to evaluate the effectiveness of UIT/UP application for fatigue life improvement of welded elements made from $350 \mathrm{MPa}$ and $700 \mathrm{MPa}$ yield strength steels that were also compared to results from TIG-dressing treatment [13]. The fatigue specimens were designed as $80 \mathrm{~mm}$ wide by $8 \mathrm{~mm}$ thick steel plates with longitudinal non-load carrying fillet welded attachments, as shown in Figure 5a.

All testing has been conducted under constant amplitude axial tension in servo-hydraulic fatigue testing machines. The applied stress ratio has been $\mathrm{R}=0.1$, with test frequencies varying from 2 to $6 \mathrm{~Hz}$ depending on load levels. Failure is defined to have taken place upon complete separation of the specimen. The results of fatigue testing are presented in Figure 5b. As can be seen from Figure 5b and table 1 below, the UIT/UP provided significant increase in fatigue performance of considered welded element for $700 \mathrm{MPa}$ yield strength steel. The increase in limit stress range at 2 millions cycles of loading was $81 \%$ for welded samples treated by UIT/UP in comparison with as-welded condition, while TIG-dressing provided a $36 \%$ increase in limit stress range of welded element (see Table 1).

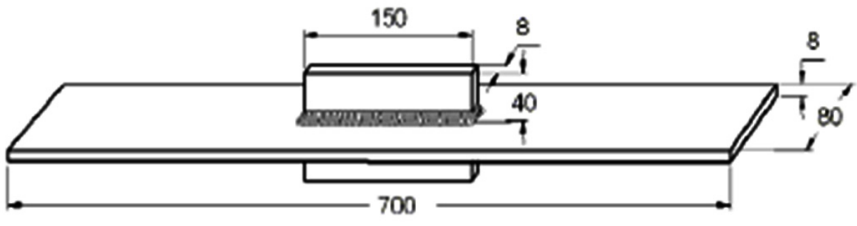

$a$

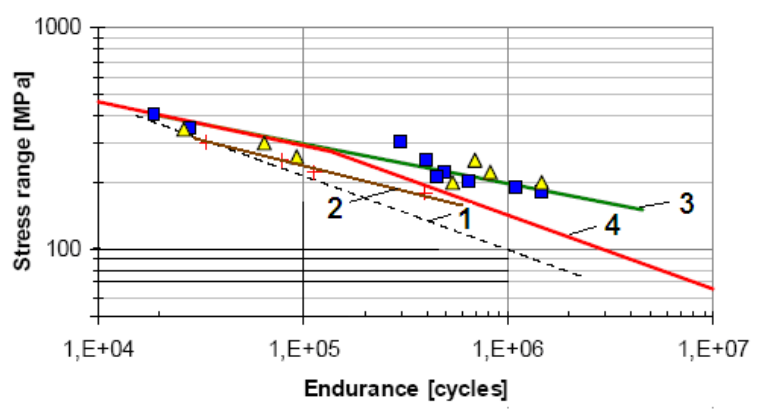

$b$

Fig. 5. UP treatment of high strength steel samples. a) Schematic of a welded specimen made of 350 and 700 MPa yield strength steel and designed for fatigue testing [13]; b) Results of fatigue testing for 350 and 700 MPa yield strength steel welded specimens [13]: 1- in as-welded condition, 350 MPa and 700 MPa yield strength steels, 2 - after UIT, 350 MPa yield strength steel, 3- after UIT/UP, 700 MPa yield strength steel, 4- FAT 112 design curve

Increase in Limit Stress Range of Welded Element Treated by UP and TIG at 2 Millions Cycles of Loading [13]

\begin{tabular}{|c|c|c|c|}
\hline S-N Curve & Slope, $\mathbf{m}$ & $\begin{array}{c}\text { FAT value } \\
{[\mathbf{M P a}]}\end{array}$ & Improvement in FAT value [\%] \\
\hline As-welded S355 and S700 & -3 (fixed) & 71.3 & 81 \\
\hline UIT/UP S700 & -5 (fixed) & 129.4 & 36 \\
\hline Robotized TIG-dressing S700 & -3 (fixed) & 97.0 & - \\
\hline
\end{tabular}

In a different study, four series of large-scale welded samples were subjected also to fatigue testing to evaluate the effectiveness of UIT/UP and LTT electrode's applications for fatigue life improvement of welded elements made from $960 \mathrm{MPa}$ yield strength steel [14]. The fatigue specimens were designed as $50 \mathrm{~mm}$ wide by $6 \mathrm{~mm}$ thick steel plates with longitudinal non-load carrying fillet welded attachments, as shown in Figure 6 a.

The testing has been conducted under constant amplitude using $\mathrm{R}=-1$. All of the as-welded specimens failed at the weld toe at the end of the longitudinal stiffeners. For the improved by UIT/UP welds, tested using constant amplitude loading, a variety of other failure modes were observed. The results of fatigue testing are presented in Figure 
6b. As can be seen from Figure 6b, the UIT/UP treatment with an instrument based on piezoelectric transducer provided the highest increase in fatigue performance of considered welded element for $960 \mathrm{MPa}$ yield strength steel in comparison with the efficiency of application of magnetostrictive transducer and LTT electrodes.

6
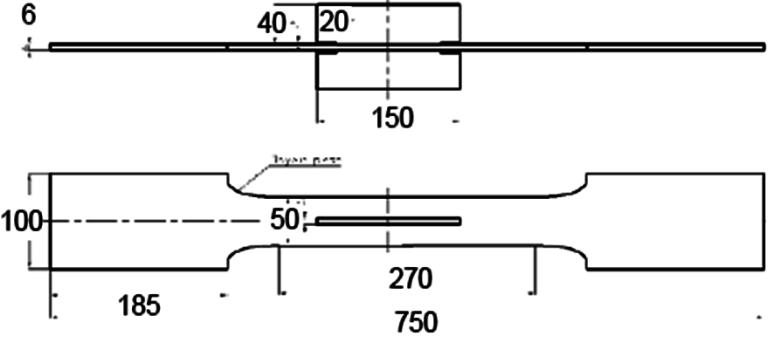

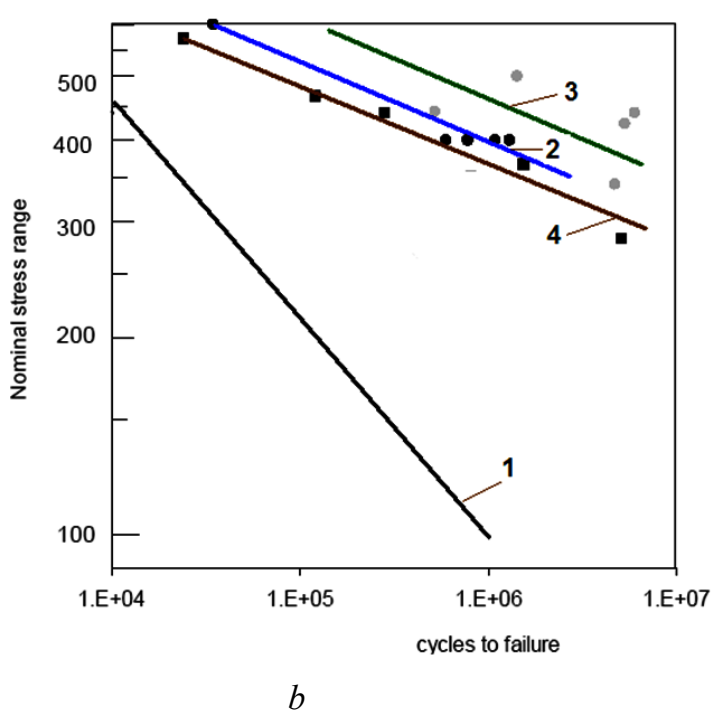

$b$

Fig. 6. UP treatment of high strength steel samples. a) Specimen geometry for fatigue testing of $960 \mathrm{MPa}$ yield strength steel welded elements [14]; b) Fatigue test results for $960 \mathrm{MPa}$ yield strength steel welded specimens [14]: 1- in as-welded condition (results of approximation of fatigue data received earlier), 2 and 3 - after UIT/UP based on using magnetostrictive and piezoelectric transducers respectively, 4- after application of LTT electrodes

\title{
Conclusions
}

In summary, the developed computerized complex for UP was successfully used in different applications in Railway and Highway Bridges, Mining, Construction Equipment, Shipbuilding, Automotive and Aerospace industries for increasing the fatigue life of welded elements. It was shown that the Ultrasonic Impact Treatment (UIT/UP), while being a relatively new technique, demonstrated very promising results in fatigue life improvement of welded elements and structures in materials of different strength including HSS with the yield strength of 700-1000 MPa. The results of fatigue testing show a strong tendency of increasing of fatigue strength of welded elements after application of UP for materials with increased mechanical properties, thus allowing using to a greater degree the advantages of the HSS in welded elements, subjected to fatigue loading.

The fatigue testing of welded specimens also demonstrated that the UP is the most efficient improvement treatment as compared with such post weld techniques as TIG-dressing and application of LTT electrodes. While not discussed I $n$ this paper, UP was used successfully in many applications for elimination of distortions caused by welding and other technological processes, relieving of residual stress, increasing of the hardness of material surfaces and surface nanocrystallization.

\section{Эффективность ультразвуковой обработки в увеличении долговечности сварных элементов и конструкций}

\author{
Якоб Клейман, Юрий Кудрявцев, Александр Луговской
}

\begin{abstract}
Аннотация. Ультразвуковая ударная обработка (UIT) является относительно новым и перспективным процессом улучшения усталостной прочности сварных элементов и конструкиий. В большинстве промышленных применений этот прочесс известен как ультразвуковая обработка (UP). Благоприятный эффект UP достигается путём снятия растягивающих остаточных напряжений и введения сжимающих остаточных напряжений в поверхностные слои материала. Вторичныли факторами повышения усталости UP являются уменьшение концентрачии напряжений в зонах сварного шва и улучшение механических свойств поверхностных слоев материала. Усталостные испытания сварных образиов показали, что UP является наиболее эффективным методом улучшения долговечности по сравнению с такими традиционными обработками как шлифование, термообработка, механическая ударная обработка и применение электродов с низкотемпературными переходами (LTT). Разработанный компьютеризированный комплекс для ультразвуковой ударной обработка успешно применялся для продления усталостного срока службы и коррозионной стойкости сварных элементов, устранения искажений, вызванных сваркой и другими технологическими проиессами,
\end{abstract}


снятия остаточных напряжений, повышения твердости поверхности материалов. Ультразвуковая ударная обработка может эффективно применяться для улучшения усталостной прочности при производстве, восстановлении и ремонте сварных элементов и конструкиии. Области / отрасли, в которых ультразвуковая ударная обработка была успешно применена, включают: судостроение, железнодорожные и шоссейные мосты, строительное оборудование, горное дело, автомобилестроение, аэрокосмическую промылиленность. Результаты усталостных испьтаний сварных элементов, проведённых как сразу после сварки, так и после применения ультразвуковой ударной обработки рассмотрень в этой статье. Показано, что UР является наиболее эффективным и экономичным методом повышения усталостной прочности сварных элементов в материалах различной прочности. Эти результаты также демонстрируют сильную тенденцию к увеличению усталостной прочности сварных элементов после применения ультразвуковой ударной обработки с увеличением механических свойств используемого материала.

Ключевые слова: остаточные напряжения; ультразвуковой метод упрочнения; подводная ультразвуковая ударная обработка; UltraPeеn $\AA ;$ усталостная прочность

\title{
Ефективність ультразвукової обробки при збільшенні довговічності зварних з'сднань та конструкцій
}

\author{
Якоб Клейман, Юрій Кудрявцев, Олександр Луговський
}

Анотація. Ультразвукова ударна обробка (UIT) є відносно новим і перспективним процесом покращення втомної міцуності зварних елементів та конструкиій. В більшості промислових застосувань цей процес відомий як ультразвукова обробка (UP). Сприятливий ефект UP досягається шляхом зняття залишкових напружень, щзо розтягують, $і$ введення залишкових напружень, щуо стискають, в поверхневі шари матеріалу. Вторинними факторами підвищення втоми UР $є$ зменшення концентрації напружень в зонах зварного шва і поліпшення механічних властивостей поверхневих шарів матеріалу. Втомні випробування зварних зразків показали, що UP є найбільш ефективним методом поліпшення довговічності в порівнянні з такими традиційними обробками як иліфування, термообробка, механічна ударна обробка $і$ застосування електродів з низькотемпературними переходами (LTT). Розроблений комп'ютеризований комплекс для ультразвукової ударної обробки було успішно застосовано для продовження втомного терміну служби і корозійної стійкості зварних елементів, усунення спотворень, викликаних зварюванням та іншими технологічними процесами, зняття залишкових напружень, підвищення твердості поверхні матеріалів. Ультразвукова ударна обробка може ефективно застосовуватися для поліпшення втомної міцуності при виробництві, відновленні і ремонті зварних елементів і конструкиій. Області / галузі, в яких ультразвукова ударна обробка була успішно застосована, включають: суднобудування, залізничні і шосейні мости, будівельне обладнання, гірнича справа, автомобілебудування, аерокосмічна промисловість. Результати втомних випробувань зварних елементів, проведених як відразу після зварювання, так і після застосування ультразвукової ударної обробки, розглянуті в ијій статті. Показано, щзо UP є найбільш ефективним $і$ економічним методом підвищення втомної міцності зварних елементів в матеріалах різної міцуності. Ці результати також демонструють сильну тенденцію до збільшення втомної міцуності зварних елементів після застосування ультразвукової ударної обробки зі збільшенням механічних властивостей матеріалу, щуо використовується.

Ключові слова: залишкові напруження; ультразвуковий метод збільшення; підводна ультразвукова ударна обробка;

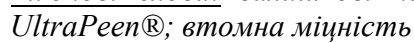

\section{References}

1. Trufyakov, V., Mikheev, P. and Kudryavtsev, Y. (1995), "Fatigue Strength of Welded Structures. Residual Stresses and Improvement Treatments", Harwood Academic Publishers GmbH. London, p. 100.

2. Kudryavtsev, Y., Korshun, V. and Kuzmenko, A. (1989), Improvement of Fatigue Life of Welded Joints by Ultrasonic Impact Treatment. Paton Welding Journal, No. 7, pp. 24-28.

3. Trufyakov, V., Mikheev, P., Kudryavtsev, Y. and Reznik, D. (1993), "Ultrasonic Impact Peening Treatment of Welds and Its Effect on Fatigue Resistance in Air and Seawater", Proceedings of the Offshore Technology Conference, OTC 7280 pp. 183-193.

4. Kudryavtsev, Y., Mikheev, P. and Korshun, V. (1995), "Influence of Plastic Deformation and Residual Stresses Created by Ultrasonic Impact Treatment on Fatigue Strength of Welded Joints", Paton Welding Journal, No. 12. pp. 3-7.

5. Trufiakov, V., Mikheev, P., Kudryavtsev, Y. and Statnikov, E. (1995), "Ultrasonic Impact Treatment of Welded Joints", International Institute of Welding, IIW Document XIII-1609-95.

6. Kudryavtsev, Y. and Kleiman, J. (2009), "Fatigue Improvement of Welded Elements and Structures by Ultrasonic Impact Treatment (UIT/UP)", International Institute of Welding, IIW Document XIII-2276-09.

7. Kudryavtsev, Y. and Kleiman, J. (2010), "Increasing Fatigue Strength of Welded Elements and Structures by Ultrasonic Impact Treatment", International Institute of Welding, IIW Document XIII-2318-10.

8. Patent of USA \# 6467321. (2002), "Device for Ultrasonic Peening of Metals.

9. Kudryavtsev, Y., Kleiman, J., Lobanov, L. and dr. (2004), Fatigue Life Improvement of Welded Elements by Ultrasonic Peening", International Institute of Welding, IIW Document XIII-2010-04, 20 p. 
10. Kudryavtsev, Y., Kleiman, J., Lugovskoy, A. and dr. (2005), "Rehabilitation and Repair of Welded Elements and Structures by Ultrasonic Peening”, International Institute of Welding, IIW Document XIII-2076-05, 13 p.

11. Kudryavtsev, Y., Kleiman, J., Lugovskoy, A. and dr. (2006), "Fatigue Life Improvement of Tubular Welded Joints by Ultrasonic Peening”, International Institute of Welding, IIW Document XIII-2117-06, 24 p.

12. Kudryavtsev, Y., Kleiman, J. and Iwamura, Y. (2009), "Fatigue Improvement of HSS Welded Elements by Ultrasonic Peening", Proceedings of the International Conference on High Strength Steels for Hydropower Plants, July 20-22, Takasaki, Japan.

13. Haagensen, P. (2005), "Progress Report on IIW WG2 Round Robin Fatigue Testing Program on 700 MPa and 350 MPa YS Steels", International Institute of Welding, IIW Document XIII-2081-05.

14. Marquis, G. and Björk, T. (2008), "Variable Amplitude Fatigue Strength of Improved HSS Welds”, International Institute of Welding, IIW Document XIII-2224-08.

15. Kudryavtsev, Y. (2008), "Residual Stress”, Springer Handbook on Experimental Solid Mechanics, Springer - SEM., pp. 371-387.

16. Reo D. Grey and James R. Denison (1944), Scaling Tool, USA, Patent No. 2,356,314.

17. Joseph F. Niedzwiecki (1967), Descaling Tool, USA, Patent No. 3,349,461.

18. Krilov, N.A., Polishchuk, A.M. (1970), Using of ultrasonic apparatus for metal structure stabilization. Physical background of industrial using of ultrasound, LDNTP, Part 1, Leningrad, Russian.

19. Robert C., McMaster and Charles C. Libby (1971), Metal Working Apparatus and Process, USA, Patent No. 3,609,851.

20. Charles C. Libby and William J. White (1971), Intermediary Impact Device, USA, Patent No. 3,595,325.

21. Feng, C. and Graff, K. (1972), Impact of a Spherical Tool against a Sonic Transmission Line, The Journal of the Acoustical Society of America, Vol. 52, No. 1, Part 2, pp. 254-259.

22. Polozky, I. Nedoseka, A. Prokopenko, G. and dr. (1974), Relieving of welding residual stresses by ultrasonic treatment, The Paton Welding Journal, no. 5, pp. 74-75.

23. Statnikov, E., Zhuravlev, L., Alexeyev, A., Bobylev, Yu., Shevtsov, E., Sokolenko, V. and Kulikov, V. (1975), Ultrasonic head for strain hardening and relaxation treatment, Russian, Author's Certificate (USSR), no. 472782.

24. Prokopenko, G. and Krivko, V. (1978), Ultrasonic multiple-strikers device, Russian, Author's Certificate (USSR), no. 601143.

25. Langenecker, B. (1966), "Effects of Ultrasound on Deformation Characteristics of Metals", IEEE Transactions on Sonics and Ultrasonics, Vol. SU-13, No. 1, March, pp. 1-8.

26. Kudryavtsev, Yuri, Kleiman, Jacob and Lugovskoy, Alexander (2013), "Underwater Ultrasonic Peening of Welede Elements and Structures", Proceedings of the 4th International Conference on INTEGRITY, RELIABILITY and FAILURE (IRF2013), Funchal, Portugal, 23-27 June.

27. Tao, N.R., Wang, Z.B., Tong, W.P. and dr. (2002), “An investigation of surface nanocrystallization mechanism in Fe induced by surface mechanical attrition treatment”, Acta Materialia, no. 50, pp. 4603-4616. 